Fedchuk, A., Sinna, O., Milinevsky, G., Utevsky, A.: The harmonization of small-scale marine spatial protection in the Argentine Islands area (Antarctic Peninsula) under the Antarctic Treaty System,

Ukrainian Antarctic Journal, 1, 111-119, 2020.

doi:10.33275/1727-7485.1.2020.384
Міжнародне співробітництво: суспільно-географічні

та політико-правові аспекти освоєння Антарктики

International Co-Operation: Socio-Economic, Political and Legal Issues of Antarctic Exploration

\author{
A. Fedchuk ${ }^{1, *}$, O. Sinna ${ }^{2}$, G. Milinevsky ${ }^{1,3,4}$, A. Utevsky ${ }^{1,2}$ \\ ${ }^{1}$ State Institution National Antarctic Scientific Center, Ministry of Education \\ and Science of Ukraine, Kyiv, 01601, Ukraine \\ ${ }^{2}$ V.N. Karazin Kharkiv National University, Kharkiv, 61022, Ukraine \\ ${ }^{3}$ Taras Shevchenko National University of Kyiv, Kyiv, 01601, Ukraine \\ ${ }^{4}$ College of Physics, International Center of Future Science, Jilin University, Changchun, 130012, China \\ * Corresponding author: fedchuk@uac.gov.ua
}

\title{
The harmonization of small-scale marine spatial protection in the Argentine Islands area (Antarctic Peninsula) under the Antarctic Treaty System
}

\begin{abstract}
The purpose of the article is to summarize the results of field studies carried out in the framework of the State Antarctic Research Program for 2011-2020 and undertaken to identify areas of special interest for small-scale marine spatial protection in the Argentine Islands water area. The scientific results reported in the publications and relevant meetings' documents officially presented by the Ukrainian delegation in 2012-2019 were summarized and interpreted in view of the Antarctic Treaty System (ATS) provisions on marine spatial protection. GIS analysis was applied to field data. It is shown that the development of protection regime for small-scale underwater landscape is based on systematic biogeographical data collected during seasonal and year-round Ukrainian Antarctic expeditions in 2011-2019. In order to harmonize the application of all available tools of spatial ecosystem-based protection across the ATS, it is proposed to designate the long-term environmental monitoring sites around Ukrainian Antarctic Akademik Vernadsky station as a new Antarctic Specially Protected Area (ASPA) consisting of terrestrial and marine components. It is shown that the marine component of the proposed ASPA could serve as one of the scientific reference areas of the broad-scale Marine Protected Area in Domain 1 within the Antarctic Peninsula region for assessing the impact of climate change on benthic communities, as well as breeding success and distribution of penguin colonies.
\end{abstract}

Keywords: Argentine Islands, Antarctic Peninsula, marine environment, protected areas, Antarctic Treaty System

\section{Introduction}

Environmental protection, including protection of marine environment, is an integral management objective of the Antarctic Treaty System (ATS) (ATCM, 2011). Antarctica is the only area of the planet beyond national jurisdictions (the Southern Ocean is just under $10 \%$ of the global marine area, more than twice the area of the Arctic Ocean or the Antarctic continent itself), characterized by the environmental regime with proactive implementation of spatial protection and management measures. As a result, the protected area network was established under the provisions of the Annex V (Area Protection and Management) to the Protocol on Environmental Protection to the Antarctic Treaty. More specifically, under Annex V an Antarctic Specially Protected Area (ASPA) can include any marine area protecting "outstanding environmental, scientific, historic, aesthetic or wilderness values, any combination of those values, or ongoing or planned scientific research".

While Articles 2, 3 and 4 Annex V include "any marine area", the designation by the Antarctic Treaty Parties of a number of ASPAs, however, is primarily 
terrestrially-focused and their geographical distribution is still unrepresentative in terms of generally used continent-wide classifications of the Antarctic environment (Shaw et al., 2014; Hughes et al., 2016; Roura et al., 2018; Wauchope et al., 2019). Only 11 ASPAs out of 73 have marine components. The largest ASPA is more than $1000 \mathrm{~km}^{2}$, while the area of others is not exceeding $10 \mathrm{~km}^{2}$. The four ASPAs have the area even less than $1 \mathrm{~km}^{2}$. Although there are some ASPAs with buffer zones extending 10-100 m around islands (ATCM, 2014).

In order to provide a strategic up-scaling approach to spatial protection of marine biodiversity there was established a network of up to regional-wide scale Marine Protected Areas (MPA) under the provisions of the Convention on the Conservation of Antarctic Marine Living Resources, CCAMLR (Brooks, 2013; Wenzel et al., 2016). At present, the two largest Antarctic MPAs are located in the South Orkney Islands southern shelf area (Brooks, 2019) and in the Ross Sea region (Brooks et al., 2019). Additional MPA proposals for East Antarctica, the Weddell Sea (Teschke et al., 2019), and the Antarctic Peninsula region (Sylvester, Brooks, 2020) are currently discussed under the CCAMLR.

However, there is a general understanding among the Antarctic Treaty Parties and conservation science assemblies that the list of Antarctic protected areas, especially with relevant marine environments, needs expanding according to a systematic environmentalgeographic framework as referred to in Article 4(2) of Annex V of the Protocol on Environmental Protection to the Antarctic Treaty (Hughes et al., 2013; Brooks et al., 2016; Chown et al., 2017; Hughes, Grant, 2017; Coetzee et al., 2017).

One of the focus areas for these needs is the Ukrainian Antarctic Akademik Vernadsky station area in the Argentine Islands (Wilhelm Archipelago, Antarctic Peninsula). There are representative examples of major terrestrial, glacial and marine ecosystems within the area. Therefore, the aim of this work is to summarize the results of field studies carried out in the framework of the State Antarctic Research Program for 2011-2020 and designed to identify areas of specific interest for small-scale marine spatial protection in the Argentine Islands waters in accordance with the legal provisions of the ATS with particular attention to the Protocol on Environmental Protection to the Antarctic Treaty.

The Argentine Islands area with adjusted costal oases of Graham Coast (Antarctic Peninsula) are the areas of particular interest of current and future scientific research. It is one of the richest regions in terms of Antarctic biodiversity, with an important set of species including lichens and invertebrates, and breeding colonies of birds and marine mammals which are very sensitive to observed global changes (Parnikoza et al., 2018). From an ecological standpoint, the water area of the Argentine Islands offers exceptional opportunities to long-term study of marine biodiversity, particularly the composition, structure and dynamics of accessible marine communities.

Since 2003 Ukraine has conducted multi-faceted research in this area, including underwater and acoustic surveys, chemical analyses of seabed sediments and soils of coastal areas. Importantly, Ukraine has studied the fast growing gentoo penguin colonies within the area, including the establishment of remote timelapse cameras in 2016, as part of the CCAMLR Environmental Monitoring Program (CEMP) and participation in CCAMLR penguin tagging project (Hinke et al., 2018; Hinke et al., 2019).

According to the objectives of the CEMP project "Establishing a Camera Network in CCAMLR Subarea 48.1", run by USA, Argentina, Australia, Poland and Ukraine, nine time-lapse cameras have been installed in the 2015/2016 season at the growing gentoo colony in the area near the Argentine Islands (Hinke et al., 2018). The cameras have been placed in the CEMP sites at Galindez Island, Petermann Island, and Yalour Islands. Cameras were operated successfully during 2016/18, as well as 2016/17 and 2018/19 seasons. An advantage of having three cameras at Galindez Island is the possibility for supervising by biologist winterers who validate the penguin chronology by direct observation.

Meanwhile, the studied area, and Antarctica as a whole, are mainly being affected by two types of human activity: scientific exploration (with corresponding impact by logistics operations) and fast-growing 
tourist activity, both have a significant impact on the Antarctic ecosystems. According to recent reports of the International Association of Antarctica Tour Operators (IAATO), during the 2018/19 Antarctic season, the total number of visitors traveling with IAATO Operators was 56168 tourists, representing an increase of about $9 \%$ compared to the previous season. Lynch et al. (2010) found that tourist landings and marine traffic are highly concentrated at a few specific locations. Tourist activity here has grown rapidly at specific locations between Lemaire Channel and Penola Strait, including Hovgaard Island, Pleneau Island, Petermann Island, Yalour Islands as well as the $\mathrm{Ar}-$ gentine Islands.

Therefore, this area and its benthic fauna in particular are of exceptional scientific interest and require special management to ensure long-term protection from potential harmful interference.

\section{Materials and methods}

The scientific articles and relevant informational papers presented by the Ukrainian delegation for the consideration in the CCAMLR Scientific Committee and its Working Group on environmental monitoring and management in 2012-2019 were interpreted through the legal provisions on marine spatial protection under the Antarctic Treaty System, including the provisions of the Annex V (Area Protection and Management) to the Protocol on Environmental Protection to the Antarctic Treaty itself, as well as the guidelines adopted by the Antarctic Treaty Consultative Meeting (ATCM) to assist Parties in selecting sites for designation and in preparing management plans, especially the Guidelines for implementation of the Framework for Protected Areas set forth in Article 3, Annex V of the Environmental Protocol (adopted by the Special ATCM XII Resolution 1 (2000), and Revised Guide to the Preparation of Management Plans for Antarctic Specially Protected Areas (adopted by the ATCM XXXIV Resolution 2 (2011)).

Hughes et al. (2013) analyzed the historical overview of the development of environmental protection strategies in Antarctica and conflict of interest raised after the reclassification of the categories of protected areas, while Coetzee et. al. (2017) examined the current status and effectiveness of the ASPA network within the regulatory framework for environmental conservation in Antarctica and summarized the best practices of establishment and expanding protected area network by means of the systematic conservation planning.

Following this approach the methodology for integrated survey of marine environment for establishing the protective regime for small-scale underwater landscape test site, was based on available scientific data such as the state of marine benthic assemblages, the distribution of sea birds, mammals, penguin colonies, and nesting places, as well as data of the underwater and acoustic surveys, chemical analyzes of seabed sediments and primitive soils of coastal areas, collected by seasonal and year-round Ukrainian Antarctic Expeditions from 2011 to 2019.

In particular, the acoustic surveys included transects for underwater surveys to describe biodiversity of benthic assemblages at depths of 1, 5, 10, 15, 20$30 \mathrm{~m}$, calculation of common species productivity indicators. The description of stationary underwater landscapes is carried out according to the standardized Natural Geography In Shore Areas (NaGISA) method. To develop a 3D-map of the seabed landscape the acoustic survey and underwater mapping have been provided. A transect is established perpendicular to the coastline using GPS. The distance between transects was chosen in accordance with the morphological features of the coastline and the seabed. At each transect, according to the NaGISA method, benthos was qualitatively sampled at intervals of $5 \mathrm{~m}$ starting from the depth of $1 \mathrm{~m}$ (taking into account the maximal and minimal tide) to the depth of $30 \mathrm{~m}$. For this purpose, a $25 \times 25 \mathrm{~cm}$ counting frame is used. Each sampling point is located using GPS, to tie it to the GIS, and photographed from several angles and filmed by a video-logger to reveal details of its three-dimensional structure and possibly interaction between species in the communities. The biomass of each common species is measured. Standardized underwater images of the $25 \times 25 \mathrm{~cm}$ frames are processed in the AXIOVISION 4.8.2 (C) Carl Zeiss Micro Imaging Gmbh. software package. 
The linear sizes of the species and the projective coverage of each component of the community are determined. Biomass parameters of species are calculated according to previously developed models.

The validation of the CEMP cameras experiment was done by daily survey of fifteen nests to study the breeding chronology (Hinke et al., 2018). The results of visual observations have been compared with data from camera pictures which registered the same nests. The standard deviation (SD) for each event varies from \pm 1 to \pm 3 days for 5 control nests at each of three test sites. This delay should be taken into account when the event dates from camera data are analyzed without corresponding visual observations at other CEMP camera sites.

\section{Results}

Since 2011, the authors have been developing a methodology for integrated exploration of water areas for creation of small-scale MPA networks. The progress of the study has been widely presented by the Ukrainian delegation in the meeting documents for the consideration by the Scientific Committee of the CCAMLR and its Working Group on environmental monitoring and management in 2012-2019 (Fedchuk et al., 2019; Utevsky et al., 2018; Utevsky et al., 2015; Utevsky et al., 2014; Utevsky, 2012).

The first stage of the study of a water area begins with delineation of a coastal strip as a source of organic and inorganic substances and trace elements. Particular attention is paid to the presence and content (morphology, macroscopic and elemental composition) of primitive soils that are most often the source of these substances.

The second stage is an acoustic survey in downscan and side-scan modes using small boats and further development of a geographic information system based on 3D-reconstruction in the ArcGIS environment. These two stages allow to select places for laying transects passing to the depths of 20-40 $\mathrm{m}$ to monitor biota, and to select places for underwater observations that may differ in the uniqueness of landscapes, the presence of rare species or the level of biodiversity and the amount of biomass.
The third stage is a survey of the seabed using transects, imaging of sampling points, collection of biological samples and samples of seabed sediments. Biological samples are used to calculate the indices of biodiversity and biomass of common species. This is the basis for mathematical models of growth of common species (mollusks, echinoderms, tunicates, etc.) for non-destructive monitoring of biodiversity and biomass at standard sites. DNA barcoding and phylogenetic analysis of some benthic invertebrates (mollusks, leeches, echinoderms, crustaceans, pycnogonids, etc.) is carried out. In order to study the structure and biodiversity of benthic assemblages in the water area of the Argentine Islands, over 300 scuba-dives have been undertaken recently. Scientific scuba-dives were done to explore 11 underwater transects, image and sample zoobenthos and seabed sediments. Samples of benthic invertebrates were used to prepare a collection of voucher specimens for DNA barcoding. Moreover, biological and physicochemical analyses of seabed sediments were carried out to determine the mechanisms of their formation and the presence of trace elements.

The fourth stage is two-three years observations of changes in biodiversity, biomass and morphology of common species on selected transects, underwater landscape, the spread of megabenthos and microbenthos, and rare species. The fifth stage is creation of a 3D-model of the MPA, allocation of core and buffer zones, description of biodiversity and landscapes, and establishment of a Management Plan for submission to CCAMLR.

In the water area of the Argentine Islands, a network of small-scale test sites was selected in parts of the Meek Channel, Stella Creek, Skua Creek and Penola Strait (Figure). The network allows developing cartographic materials of the corresponding content, observing and simulating in space and time the evolution of underwater landscapes and biota under the influence of natural and anthropogenic factors.

The Stella Creek test site $\left(65^{\circ} 14.708^{\prime}-65^{\circ} 14.875^{\prime} \mathrm{S}\right.$; $\left.064^{\circ} 15.745^{\prime}-064^{\circ} 14.997^{\prime} \mathrm{W}\right)$ is located between the Marina Point and Stella Creek of Galindez Island and Winter Island. Its maximal depth is $27 \mathrm{~m}$ and total area $116020 \mathrm{~m}^{2}$ (Figure). The seabed at the Ma- 


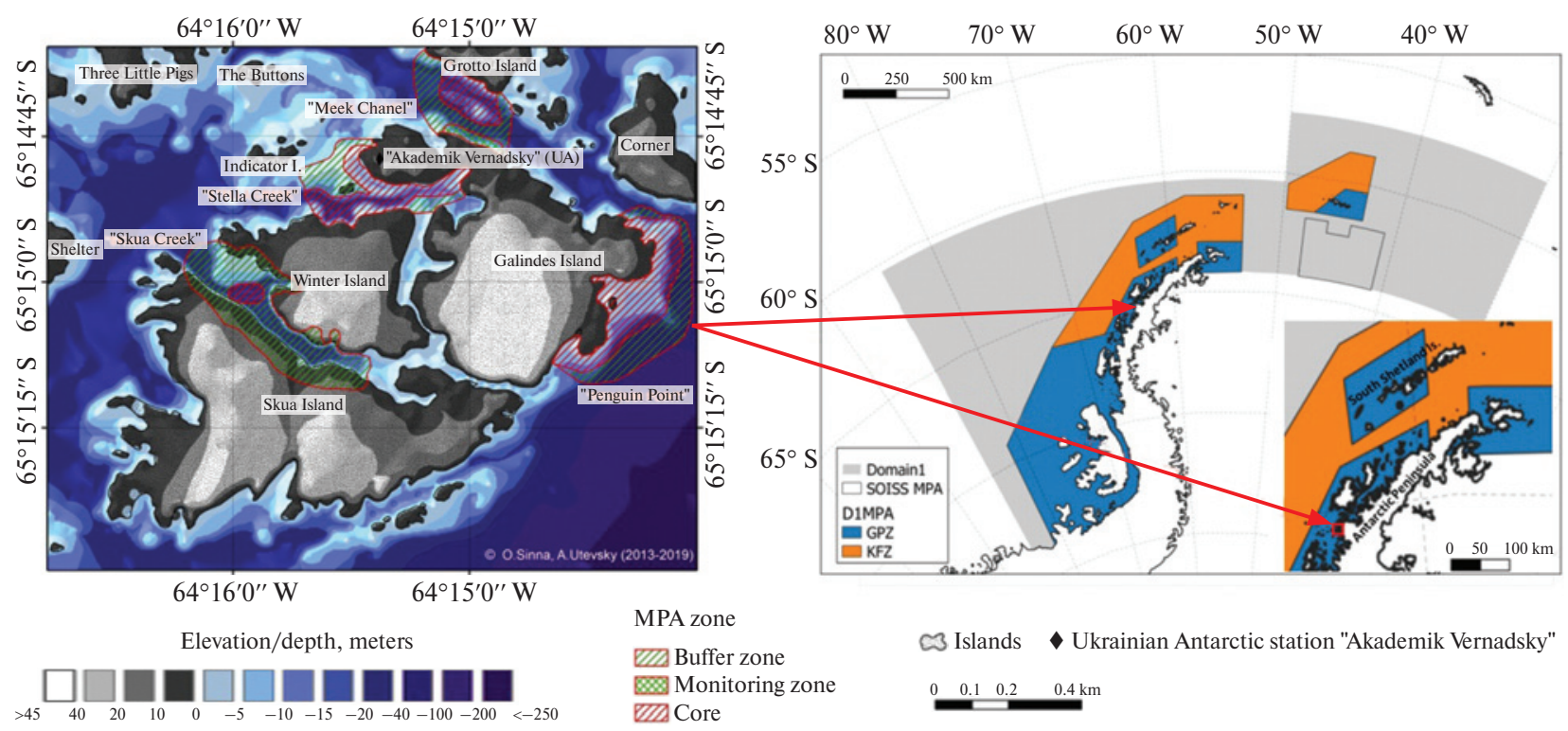

Figure. Marine component of the planned ASPA based on the network of monitoring sites within the inter-island waters of the Argentine Islands. The inset on the left shows its location as one of scientific reference areas within proposed MPA in the Domain 1 Western Antarctic Peninsula-South Scotia Arc (D1MPA), including the boundaries for the General Protection Zone (GPZ) and the Krill Fishery Zone (KFZ) (Figure from the Meeting paper CCAMLR-38/25 Rev.1 submitted by the Delegations of Argentina and Chile (2019), with permission)

rina Point test site forms a plateau up to $17 \mathrm{~m}$ deep, separated from the other water mass by ridges that form a basin. This basin passes into a narrow shallow zone $(10 \mathrm{~m})$ in the Stella Creek. In this zone, five transects were established at different depths for benthic assemblages monitoring. The shallow zone is proposed as a protected core (penguin colonies feeding area). Thumb Rock divides the shallow water and deep water zones. The deep zone (up to $29 \mathrm{~m}$ ) extends from Thumb Rock to Winter Island. The underwater landscape of the test site counteracts circulation of water masses. There is an accumulation of soft sediments with a specific fauna and specific macrozoobenthic assemblages on the vertical walls at the deep zone. The giant sponges Antarctotetilla (Tetilla) leptoderma (Sollas, 1886), Mycale (Oxymycale) acerata Kirkpatrick, 1907, Dendrilla antarctica Topsent, 1905; giant hydrozoa Candelabrum penola (Manton, 1940) with pycnogonids Decolopoda australis Eights, 1835 are members of this macrozoobenthic assemblages. The deep zone is also proposed as a protected core.
The Skua Creek test site is located at the Skua Creek Channel $\left(65^{\circ} 14.828^{\prime}-65^{\circ} 15.143^{\prime}\right.$ S; 064 $16.321^{\prime}-$ $\left.064^{\circ} 15.485^{\prime} \mathrm{W}\right)$, its max. depth is $36 \mathrm{~m}$; total area $91197 \mathrm{~m}^{2}$ (Figure). The protected core of the Skua Creek test site is proposed around the underwater rock at the $30 \mathrm{~m}$ depth. The rock (volcanic dike) is $3 \mathrm{~m}$ high, $8 \mathrm{~m}$ long and covered by filter-feeding macrozoobenthos. The macrozoobenthic assemblages exhibit high levels of biomass amount and biodiversity. Giant sponges and ascidians are present. The seabed around the rock is covered by a thick layer of soft sediments with a specific fauna of starfishes, ascidians, ophiurans, and sea spiders.

The Meek Channel test site $\left(65^{\circ} 14.580^{\prime}-65^{\circ} 14.753^{\prime}\right.$ $\mathrm{S}$; $064^{\circ} 15.203^{\prime}-064^{\circ} 14.852^{\prime} \mathrm{W}$ ) is located in the Meek Channel, between Galindez Island and Grotto Island: min. depth of $1.8 \mathrm{~m}$, max. depth of $33 \mathrm{~m} ; 53487 \mathrm{~m}^{2}$ in total (Figure). The depth of the strait is up to $33 \mathrm{~m}$ at the intersection of Galindez Island-Grotto Island. The angle of the coastal slope of Galindez Island is up to $\sim 60^{\circ}$. The coastal slope of the Grotto Island is a vertical wall which extends to a depth of up to $30 \mathrm{~m}$. 
The protected core is proposed around the underwater rock near Grotto Island. The base of the underwater rock is located $30 \mathrm{~m}$, and the top lies about $10 \mathrm{~m}$ below the surface. The unique macrozoobenthic assemblages include giant sponges $A$. leptoderma, Anoxycalyx (Scolymastra) joubini (Topsent, 1916), M. acerata, D. antarctica; starfishes Macroptychaster accrescens (Koehler, 1920), Labidiaster annulatus Sladen, 1889, Perknaster aurorae (Koehler, 1920); molluscs Dorisker guelenensis (Bergh, 1884), Marseniopsis mollis (E.A. Smith, 1902), Marseniopsis syowaensis Numanami \& Okutani, 1991 and pycnogonid D. australis. A monitoring zone with three transects is proposed near Galindez Island.

The Penguin Point test site $\left(65^{\circ} 14.807^{\prime}-65^{\circ} 15.273^{\prime}\right.$ S; $064^{\circ} 14.825^{\prime}-064^{\circ} 13.994^{\prime} \mathrm{W}$ ) is located near Galindez Island in the Penola Strait; max. depth of $177 \mathrm{~m}$; $223887 \mathrm{~m}^{2}$ total (Figure). The underwater landscape contributes to the constant circulation of water masses. The Penguin Point coast slope goes through several ledges $-6 \mathrm{~m}, 20 \mathrm{~m}-$ a well-defined abrasive zone, and then exhibits a sharp decline. Brown and red algae, especially the giant Himantothallus grandifolius (A. Gepp \& E.S. Gepp) Zinova, 1959, form an extended pad at depths up to $20 \mathrm{~m}$. At these depths there are giant starfish $M$. accrescens, up to $2 \mathrm{~kg}$, stalked jellyfish Haliclystus antarcticus Pfeffer, 1889; pycnogonids $D$. australis and Colossendeis sp. At the depth of more than $20 \mathrm{~m}$, giant starfishes Labidiaster annulatus Sladen, 1889 and Perknaster aurorae (Koehler, 1920) were found. At depths from $20 \mathrm{~m}$ to $60 \mathrm{~m}$ over fields of gorgonian corals, there dwell sea urchins Ctenocidaris speciosa Mortensen, 1910; giant polychaeta Flabegravier amundata (Gravier, 1906) and Eulagisca gigantea Monro, 1939; giant sponge Rossellara covitzae Topsent, 1901; ophiurans Ophiosparte gigas Koehler, 1922 and flattened holothurian Bathyplotes bongraini Vaney, 1914. The protected water area from nearshore zone (penguin colonies feeding area) to the $120 \mathrm{~m}$ depth with three transects is proposed.

\section{Discussion}

As Cordonnery et al. (2015) noted, the designation of MPAs within the ATS largely falls within the CCAMLR and its Working Groups responsibility. However, Annex V of the Madrid Protocol plays an important role in the overall protected area system, establishing the mechanism for designating ASPAs, which provides specific tools for spatial management and essential recognition of outstanding values in the Southern Ocean. Accordingly, ASPAs are properly regarded as a regionally implemented framework for establishing MPAs with the CCAMLR (ATCM, 2011). The establishment of effective, representative and coherent spatial protection of marine biodiversity within the Antarctic Treaty Area requires:

1) enhanced commitment and further action from the Antarctic Treaty Consultative Meetings (ATCM) to put into operation the specific objectives of the Protocol on Environmental Protection concerning marine spatial protection and management through the designation of ASPAs; and

2) increased collaboration between the ATCM and CCAMLR relating to the identification, management and monitoring of marine areas in conformity with the management objectives that are common to both bodies (ATCM, 2011).

In order to up-scale ASPA designation process and to harmonize the application of all available tools of spatial ecosystem-based protection and management across the Antarctic Treaty System, Ukraine proposed a designation of the long-term environmental monitoring sites around the Argentine Islands as a new ASPA with marine component, which will serve as one of the scientific reference areas of the broad-scale MPA in Domain 1 within the Antarctic Peninsula region for assessing the impact of climate change on benthic communities, as well as breeding success and distribution of penguin colonies (Fedchuk et al., 2019).

CCAMLR Scientific Committee encouraged Ukraine to continue the work on establishing an ASPA in the Argentine Islands and appreciated that the proponents intend to harmonize the ASPA with the MPA in the Domain 1 (Report, 2019).

\section{Conclusions}

The Argentine Islands, including adjacent islands of the Wilhelm Archipelago and costal oases of nearby 
Graham Coast Antarctic Peninsula region have important natural, scientific and educational value. That area is of considerable and increasing scientific, tourist and logistic activities. The potential conflict of interests in the area requires better management and coordination. In particular, scientific research being undertaken within the planned ASPA is important for the tracking of ecosystem interactions and long-term environmental changes, and their relations to Antarctica and the global environment in general.

Therefore, this new ASPA in the Argentine Islands is designated because of its key characteristics, including:

- representative examples of major marine ecosystems;

- important communities of species, including major colonies of breeding native birds or mammals and marine macrozoobenthos;

- particular interest to ongoing or planned scientific research.

These efforts will serve as the Ukrainian contribution to establish an effective, representative spatial protection of the terrestrial and marine biodiversity through the specific management measures within the provisions of the Antarctic Treaty System. It would be really important to achieve a harmonization of the planned ASPA with the initiatives within CCAMLR, in particular, through the possible integration of the marine component within planned ASPA into the new MPA in Domain 1 (Antarctic Peninsula), as one of scientific reference areas.

Author contributions. AF, GM: conceptualization. AF: introduction, reference review, the original draft. AU, OS: methodology, data analysis, investigation, visualization. GM, AF, AU, GM: project administration, writing, manuscript review and editing. All authors have read and agreed to the published version of the manuscript.

Competing interests. The authors declare that they have no conflict of interest.

Acknowledgements. This study is carried out in the framework of the State Special-Purpose Research Pro- gram in Antarctica for 2011-2020. The authors thank members of Ukrainian delegation to the CCAMLR, especially Kostiantyn Demianenko and Leonid Pshenichnov, for their support and valuable advises. We thank Jefferson Hinke for the CEMP Camera project supervising. The technical support of this project has been funded by the CAMLR Commission with the valuable coordination from the CCAMLR Secretariat.

\section{References}

Antarctic Treaty Consultative Meetings (ATCM): Marine spatial protection and management under the Antarctic Treaty System: new opportunities for implementation and coordination, Information Paper IP-056 submitted by the IUCN (Buenos Aires, Argentina, June 20-July 1, 2011), 9 pp., 2011.

ATCM: The role of the Antarctic Treaty Consultative Meeting in protecting the marine environment through marine spatial protection, Information Paper IP-049 submitted by The Netherlands (Brasilia, June 20-July 1, 2014), 29 pp., 2014.

Brooks, C.: Competing values on the Antarctic high seas: CCAMLR and the challenge of marine-protected areas, The Polar Journal, 3 (2), 277-300, doi:10.1080/2154896X.2013.8 54597, 2013.

Brooks, C.M.: Geopolitical complexity at the bottom of the world: CCAMLR's ongoing challenge of adopting marine protected areas, in: Governing Marine Living Resources in the Polar Regions, Edward Elgar Publishing, Cheltenham, UK, 2019.

Brooks, C.M., Crowder, L.B., Curran, L.M., Dunbar, R.B., Ainley, D.G., Dodds, K-J., Gjerde, K.M., Sumaila, U.R.: Science-based management in decline in the Southern Ocean, Science, 354 (6309), 185-187, doi:10.1126/science.aah4119, 2016.

Brooks, C.M., Crowder, L.B., Österblom, H., Strong, A.L.: Reaching consensus for conserving the global commons: the case of the Ross Sea, Antarctica, Conservation Letters, 13 (1), e12676, doi:10.1111/conl.12676, 2019.

Chown, S.L., Brooks, C.M., Terauds, A., Le Bohec, C., van Klaveren-Impagliazzo, C., Whittington, J.D., Butchart, S.H.M., Coetzee, B.W.T., Collen, B., Convey, P., ... McGeoch, M.A.: Antarctica and the strategic plan for biodiversity, PLoS Biology, 15 (3), e2001656, doi:10.1371/journal.pbio.2001656, 2017.

Coetzee, B.W.T., Convey, P., Chown, S.L.: Expanding the protected area network in Antarctica is urgent and readily achievable, Conservation Letters, 10 (6), 670-680, doi:10.1111/ conl.12342, 2017.

Cordonnery, L., Hemmings, A.D., Kriwoken, L.: Nexus and Imbroglio: CCAMLR, the Madrid Protocol and Designating Antarctic Marine Protected Areas in the Southern Ocean, International Journal of Marine and Coastal Law, 30 (4), 727-764, doi:10.1163/15718085-12341380, 2015. 
Delegations of Argentina and Chile, Revised proposal for a conservation measure establishing a Marine Protected Area in Domain 1 (Western Antarctic Peninsula and South Scotia Arc), Meeting Document CCAMLR-38/25 Rev.1, Hobart, Australia, 2019.

Fedchuk, A., Parnikoza, I., Kozeretska, I., Berezkina, A., Sinna, O., Utevsky, S., Levenets, V., Utevsky, A., Pshenichnov, L., Demianenko, K., Milinevsky, G., Dykyi, E.: Preliminary proposal for designation an Antarctic Specially Protected Area in the Argentine Islands Archipelago and nearby Graham Coast Antarctic Peninsula region, Meeting Document SC-CAMLR-38/BG/21 Rev. 1, Hobart, Australia, 2019.

Hinke, J.T., Barbosa, A., Emmerson, L.M., Hart, T., Juáres, M.A., Korczak-Abshire, M., Milinevsky, G., Santos, M., Trathan, P.N., Watters, G.M., Southwell, C.: Estimating nestlevel phenology and reproductive success of colonial seabirds using time-lapse cameras, Methods in Ecolology and Evolution, 9 (8), 1853-1863, doi:10.1111/2041-210X.13015, 2018.

Hinke, J.T., Santos, M.M., Korczak-Abshire, M., Milinevsky, G., Watters, G.M.: Individual variation in migratory movements of chinstrap penguins leads to widespread occupancy of ice-free winter habitats over the continental shelf and deep ocean basins of the Southern Ocean, PLoS ONE, 14 (12), e0226207, doi:10.1371/journal.pone.0226207, 2019.

Hughes, K.A., Grant, S.M.: The spatial distribution of Antarctica's protected areas: A product of pragmatism, geopolitics or conservation need? Environmental science \& Policy, 72, 41-51, doi:10.1016/j.envsci.2017.02.009, 2017.

Hughes, K.A., Ireland, L.C., Convey, P., Fleming, A.H.: Assessing the effectiveness of specially protected areas for conservation of Antarctica's botanical diversity, Conservation Biology, 30 (1), 113-120, doi:10.1111/cobi.12592, 2016.

Hughes, K.A., Pertierra, L.R., Walton, D.W.H.: Area protection in Antarctica: How can conservation and scientific research goals be managed compatibly? Environmental science \& Policy, 31, 120-132, doi:10.1016/j.envsci.2013.03.012, 2013.

Lynch, H.J., Crosbie, K., Fagan, W.F., Naveen, R.: Spatial patterns of tour ship traffic in the Antarctic Peninsula region, Antarctic Science, 22 (2), 123-130, doi:10.1017/S09541020 09990654, 2010.

Parnikoza, I., Berezkina, A., Moiseyenko, Y., Malanchuk, V., Kunakh, V.: Complex survey of the Argentine Islands and Galindez Island (Maritime Antarctic) as a research area for studying the dynamics of terrestrial vegetation, Ukrainian Antarctic Journal, 1 (17), 73-101, doi:10.33275/1727-7485.1 (17).2018.34, 2018.

Report of the Thirty-eighth meeting of the CCAMLR Scientific Committee, Paragraphs 6.11-6.12, Hobart, Australia, 21 to 25 October 2019, 2019.
Roura, R., Steenhuisen, F., Bastmeijer, K.: The shore is the limit: marine spatial protection in Antarctica under Annex V of the Environmental Protocol to the Antarctic Treaty, The Polar Journal, 8 (2), 289-314, doi:10.1080/2154896X.2018.1 541549, 2018.

Shaw, J.D., Terauds, A., Riddle, M.J., Possingham, H.P., Chown, S.L.: Antarctica's Protected Areas Are Inadequate, Unrepresentative, and at Risk, PLoS Biology, 12 (6), 1-5, doi:10.1371/journal.pbio.1001888, 2014.

Sylvester, Z.T., Brooks, C.M.: Protecting Antarctica through Co-production of actionable science: Lessons from the CCAMLR marine protected area process, Marine Policy, 111, 103720, doi:10.1016/j.marpol.2019.103720, 2020.

Teschke, K., Pehlke, H., Siegel, V., Bornemann, H., Knust, R., Brey, T.: An integrated data compilation for the development of a marine protected area in the Weddell Sea, Earth System Science Data Discussions, 1-31, doi:10.5194/essd2019-86, 2019.

Utevsky, A.Yu.: The first site of the Marine Protected Area network in the Akademik Vernadsky Station region: Argentine Islands, Skua Creek, Meeting Document, Meeting of the Commission on the Conservation of Antarctic Marine Living Resources, CCAMLR, 2-13 Jul 2012: WG-EMM-12/25, 2012.

Utevsky, A.Yu., Sennaya, E.I., Kolesnykova, M.Yu.: Realization of the Marine Protected Area network in the Akademik Vernadsky Station region, CCAMLR, 21 June 2014: WG-EMM14/41, doi:10.13140/RG.2.2.30036.40325, 2014.

Utevsky, A.Yu., Tabikelova, K.S., Sennaya, E.I., Utevsky, S.Yu.: Changes of population structure in common benthic species of the proposed Stella Creek MPA in the vicinity of the Akademik Vernadsky Station, Galindez Island, Antarctica, Meeting Document, Meeting of the CCAMLR, 21 June 2015: EMM-15-41, doi:10.13140/RG.2.2.10061.03041, 2015.

Utevsky, A., Sinna, E., Smyrov, D., Shrestha, M., Gamulya, Y., Ukhno, G., Khodzhaeva, R., Utevsky, Yu., Levenets, V., Utevsky, S.: Next steps in development of Marine Protected Area in the Argentine Islands Archipelago water area, Meeting Document, Meeting of the Commission on the Conservation of Antarctic Marine Living Resources, CCAMLR, 24 June 2018: WG-EMM-18/32, 2018.

Wauchope, H.S., Shaw, J.D., Terauds, A.: A snapshot of biodiversity protection in Antarctica, Nature Communications, 10 (1), 946, doi:10.1038/s41467-019-08915-6, 2019.

Wenzel, L., Gilbert, N., Goldsworthy, L., Tesar, C., McConnell, M., Okter, M.: Polar opposites? Marine conservation tools and experiences in the changing Arctic and Antarctic, Aquatic Conservation: Marine Freshwater Ecosystems, 26 (S2), 61-84, doi:10.1002/aqc.2649, 2016.

Received: 28 December 2019 Accepted: 25 May 2020 
А. Федчук ${ }^{1, *}$, О. Сінна ${ }^{2}$, Г. Міліневський ${ }^{1,3,4}$, А. Утєвський ${ }^{1,2}$

1 Державна установа Національний антарктичний науковий центр МОН України, м. Київ, 01601, Україна

${ }^{2}$ Харківський національний університет імені В.Н. Каразіна, м. Харків, 61022, Україна

${ }^{3}$ Київський національний університет імені Тараса Шевченка, м. Київ, 01601, Україна

${ }^{4}$ Коледж фізики, Міжнародний центр науки майбутнього, Цзилінський університет, м. Чанчунь, 130012, Китай

* Автор для кореспонденції: fedchuk@uac.gov.ua

Гармонізація просторової охорони морського середовища району Аргентинських островів (Антарктичний півострів) в рамках системи Договору про Антарктику

Резюме. Метою роботи є узагальнення результатів польових досліджень, спрямованих на забезпечення охорони морського середовища в акваторії Аргентинських островів, виконаних у рамках Державної цільової науково-технічної програми проведення досліджень в Антарктиці на 2011-2020 роки. Наукові результати, висвітлені у публікаціях, присвячених цій проблематиці, а також у відповідних документах, офіційно представлених Українською делегацією у 2012-2019 роках, узагальнено з урахуванням правових норм щодо просторового регулювання охорони морського середовища в рамках Системи Договору про Антарктику (СДА). Для узагальнення результатів польових досліджень використано ГІС-аналіз. Розроблення режиму охорони для морського біогеографічного полігону базується на найкращих доступних наукових даних щодо стану морських донних угруповань, поширення морських птахів, ссавців, колоній пінгвінів та місць їхнього гніздування, а також підводних та акустичних досліджень, хімічних аналізів прибережних донних відкладів, що були зібрані під час сезонних та цілорічних українських антарктичних експедицій у 2011-2019 роках. 3 метою гармонізації застосування всіх доступних інструментів охорони та управління на основі екосистемного підходу в рамках СДА, Україна створює Антарктичний район, що особливо охороняється, (АРОО) на Аргентинських островах, прилеглих островах архіпелагу Вільгельма та прибережних оазах Антарктичного півострова. АРОО включатиме як наземну територію, так і морський компонент у складі міжострівних акваторій у межах центральної групи Аргентинських островів. Показано, що морський компонент запланованого АРОО може слугувати одним із наукових референтних районів широкомасштабного Морського охоронного району в Області планування 1 (регіон Антарктичного півострова) для оцінки впливу зміни клімату на донні угруповання, характер розповсюдження та успішність гніздування популяцій пінгвінів.

Ключові слова: Аргентинські острови, Антарктичний півострів, морське навколишнє середовище, природоохоронні райони, система Договору про Антарктику 